Historic, Archive Document

Do not assume content reflects current scientific knowledge, policies, or practices. 


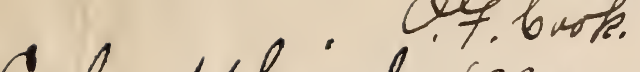

Cal. Ukiah (Mendreind C.

Pricerier

SECTION OF SEED AND PLANT INTRODUCTIOK

Retail.

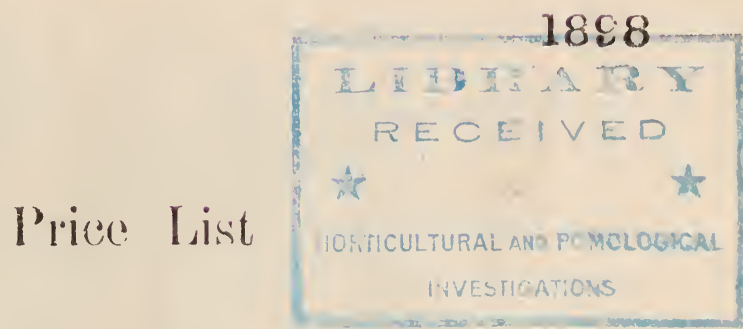

$\mathrm{OF}$

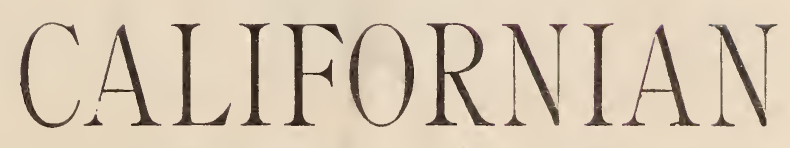

BULBS.

CARL PURDY,

COLLECTOR and GROWER,

UKIAH, MENDOCINO CO, CALIFORNIA, U. S. A. 


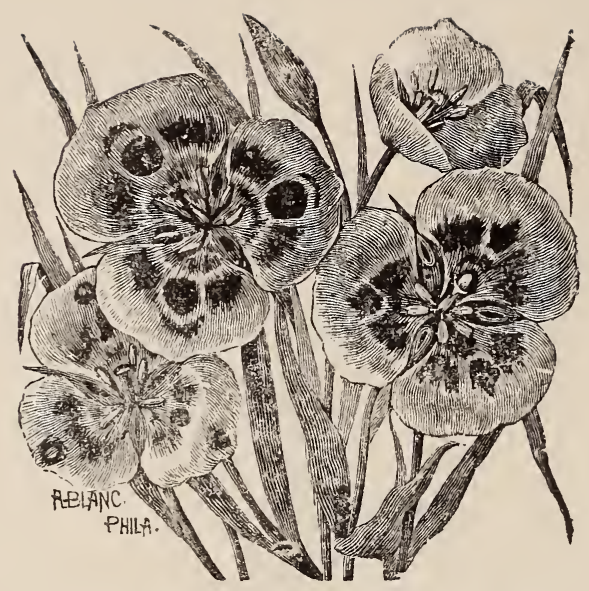

CALOCHORTUS VENUSTUS Dougl.

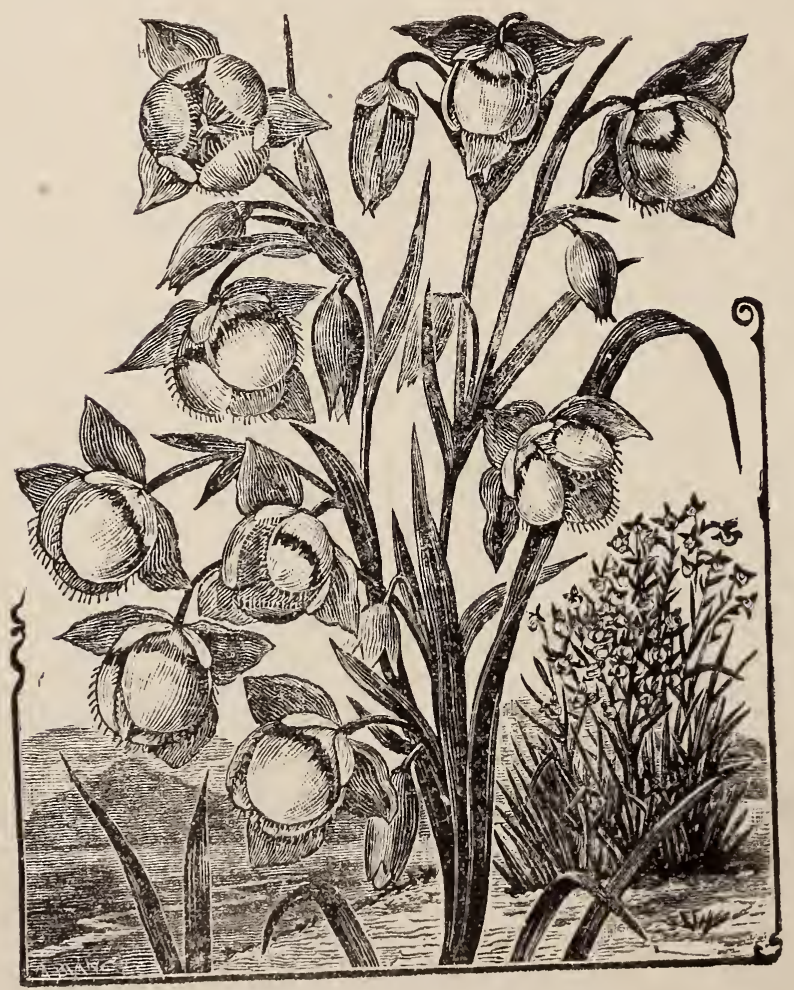

CALOCHORTLS PTIAHFLTA: D iUg:. 


\title{
REMARKS.
}

I make a specialty of Calilornian bulbs, growing largely, and through collectors reaching all parts of the Paicfic Coast of the United States.

QUALITY. - The bulbs offered are above medium grade, even in size, and with no small or imperfect ones. Extras to cover all deficiencies are always sent. In the selection and packing of bulbs the greatest of care is taken.

GUARA.NTEFS. - I guarantee that all bulbs shall reach purchaser in first-class condition, and will make good any loss in transit whether from breakage of package or decay. Claims for damages must be made within five days after receipt of gonds, and will be allowed either by replacing the bulbs or by deducting the price from bill, at my option.

GROIVN IN CULTIVATION.-The largest part of my orders will be filled from bulbs of my own growing; these are larger, solider, and better ripened than collected bulbs. first-class.

\section{Date of Ripening and Sinipment.}

Unless otherwise ordered, I make my main shipment about August rst, and send later sorts as they come in; unless specially noted, bulbs are ready August Ist.

Californian bulbs as a rule do better if planted in the fall. I keep stocks until January rst.

SUPPLIES-Unless otherwise noted, my supplies are equal to any probable demand. I make a point of filling all orders if it is any way possihle. I grow from 200.000 to 300 ooo California bulbs annually.

LARGE LOTS. - Special prices on large lots of any sort.

CARRIAGE,-I deliver all bulhs vithin the United States free of freight and express charges. I deliver all foreign orders at New York.

\section{TERMS.}

\author{
CASH WITH ORDER. \\ rovix at rate per dezen.
}

\section{Brodiæa.}

These are handsome hardy bulbous plants of the Pacific slope of the United States. They have a few grassy radical leaves, and one or several slender stalks terminating in either an open umbel, or a dense umbellate head. Reliable bloomers, growing well in almost any soil or under any conditions. Perfectly hardy in the Eastarn United States and Europe. The bulbs are easily kept dry for months, and are not at all subject to decay, and do not bruise readily, good points from a dealer's standpoint. 


\section{Section 1.}

BRODIAEA LAXA S. Watson.

Blue Milla, Ithuriel's Spear. A well grown plant of this fine species has a spreading umbel eight inches across, on a Each. Doz. sixteen inch erect stalk, and from forty to fifty tubular flowers, from blue to deep purple in color; it forces well, and its a cut flower is fine and verv lasting.....

BRODIAEA HEXDERSONII Watson.

This beautiful species is now offered for the first time in reliable supply; like the beatutiful B laxa, except it is vellow banded with purple.

\section{BRODIAEA BRIDGESII S. Watson.}

\& 10 sio

Resembling $\mathrm{R}$. laxa, but a flatter fluwer, of a rich reddishpurple; very handsome and universally adnirc d............. BRODIAEA PEDUNCULARIS S. Wat.

Like B. laxa, but fewer flowered, and having an immense umbel twenty to twenty-four inches across. Color porcelain

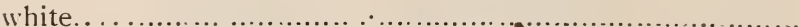

\section{BRODIAEA LACTEA S. Watson.}

Like B. laxa in habit, but having a small umbel of mom. white flowers banded with green

Var L!LACINA.

I can highly recommend this fine new form which is far larger and more vigorous than the type. 11 ith large flowers, white richly suffused with lilac

Var. MAJOR.

Like the preceding. but white

\section{BRODIAEA IXIOIDES S. Wat on.}

Of same habit as B laxa; flowers a fine yellow, banded with brown

Var MINOR Hort.

A pretty dwarf, with yellow flowers, dark band and blue anthers

Var. ERECTA. A handsome dwarfed form

Var. SPILENDFNS

Laıge light yellow flowers, far handsomer and showier

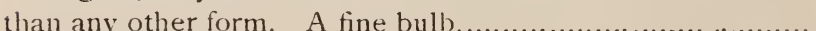

\section{BRODIAEA MINOR s. Watson.}

Like B. grandiflora, but dwarfed. The stem not rising above the soil, quite a curiosity. 


\section{Siection 11 .}

Flowers in umbels, usually sevesal stalks to each bulb; the hlossoms broad funnelform, of a peculiar thick waxy texture; very lasting.

BRODIAEA GRANDIFLORA Smith.

Fach Driz.

V'ery showy, fine, large deep purple flowers $\mathrm{O} 2$ 20 BIOII.EA CALIFORNICA.

A new species introduced by me in 1 \$95. it is like $P$. Grandiflora hut much larger in every way. Large, waxy p nk flowers.

\section{B'PODIAAA ORCLTTII}

Hand ome. smaller blue flowers in close umbels............ BRODIAEA FILIFOLIA S. Watson.

Similar and pretty $06 \quad 60$

BPODIAEA STELLARIS S. Watson.

A beautiful plant. The bulbs producing several many flowered umbels, the flowers deep blue with waxy white ce.ter. Forming a low star-like clump.

BROIILAA ROSEA.

Resembling B. stellaris, but pinkish purple. BROIIEA PLRDYI.

This handsome species is very different from all other Brodiaeas in that the flower is broally spreading with tips declining. quite handsome and novel...

BRODIAEA TERRESTRIS Kello:g.

A miniature form, with small rose purple flowers with yellow center, stems very short and the flowers often seeming to rest on the grounci. A good novelty.

BRODIAEA GRACILIS S. Watson.

A tiny species much like a litule Bloomeria

\section{Section III.--OAIIFORNIA HY.AOINTHS.}

PRODIAEA ("APITATA Benth.

A tall early bloomer, with handsome deep violet flowers in head, on long slender stalks.

GROIDLA CAPITATA. VAR, HLBA.

This splendid waxy white form is a yenuine acquisition. There is no puler white in nature. It should be grown extensively

BRODIAA CAPITATA VAR. PARVIFLORA.

A very floriferous form of $P$. capitata. low giowing with several stalks. The flowers are exactly the color of the English violet, and a bunch of them could be readily passed for them 
BRODIAEA MLLTIFICRA B?nth

Each Dor.

A tall species with fine purple fluwers..................... us to

BRODIAEA CONGESTA Sm.

Three feet high when well grown. Large violet purple heads

\section{Section IV.-STROPHOLIRION.}

BRODI.モA VOLCEBIIIS

Twining Hyacinth. No more striking novely has been introduced of late years. Like B. congesta in bulbs and leaf. The stem begins twining as the tiny flower bud appears and when it is developed the loose umbel of beautiful waxy pink flowers is born aloft three to tive feet from the ground. The flower stem can be twined in odd arrangements.

\section{Section V.-BIEVOORTIA.}

\section{BPODIAEA COCCINEA A Gras.}

The floral firecracker, well shown in cut. flowers $: y / 2$ to 2 inches long. a rich glowing crimson, tipped with pea green. One of the best of novelties, and a very striking plant. Immense bulbs $I$ inch in diameter. .................... Large bulbs $; 8-1$ inch in diameter...............................

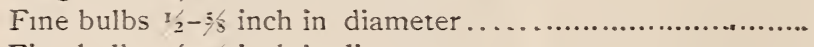
Fine bulbs $3 / 5-1 / 2$ inch in diameter.............................

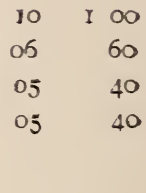

\section{BRODIAEA HOTELLII S. Watson.}

Small, and milky white to biue, but very prett..............

A splendid new thing from the State of Ilashington. Described in London Garden as follows: "Fine deen gren foliage at time of flowering. Sturdy stem two feet high, crowned by large flat umbels of nicely shaped flwers. w a very delicate blending of milky white and liac blue." Flowers very lasting Illustrated by colored plate in Garden. December I5th, IS94. Ready Sept. Ist...............

\section{BRODIAEA DOtGLASII S. Watson.}

Similar but a delicate blue, eight or ten inches high. Pritty..

\section{Mixed Brodiaeas}

I keep a splendid mixture of all the Brodireas in fine solid bulbs, sure to please........................................ 


\section{Bloomeria.}

BLOOMERIA ALREA Kellogg.

Each Doz.

The bloomerias are close to Brodixa laxa in general character, but with flat open flowers, produced in great numbers. Jight yellow. Easily groun and very pretty. It should be grown everywhere

BLOOMERTA CLEVELANDI S. Wats.

Is of smaller growth with delicate yellow flowers.. ........

\section{Calochortus.}

\section{Section I.-MARIPOSA 'TULIPS.}

This is a group whose elegance of form and fine coloring give them a high rank in the garden. Much attention is being given them in Europe and the leading floral papers speak of them in the highest terms. The bulb is small, the leaves grassy, the stem stiff and erect but slender. The exquisitely molded flowers resemble in form the tulip, while the colorings are most beautiful and varied. Bulbs easily handled and light. I have the finest collection in the world, and spare no pains to secure new and rare forms.

\section{GROUP I.-SPLENDENS.}

Each Doz.

\section{CALOCHORTUS SPLENDENS Dougl.}

The trpe of the specie- is a tall and stately plant, with larege ( 2 to 3 inches across), pale lilar flowers, paler at the ('enter, and the lower half of the petals covered with long cobwebby hairs.. .............................................

Var. ATROVIOI,ACEA.

Tall and slender but flowers one to ore and one half inches acrnss, of a deep purple color, with a dark spot in the center. Good..................................................

Var. RUPRA

A grand new form as large as type but reep reddish purple with a dark purple spni at center...

\section{CALOCHORTI'S PALMERI S. Watson.}

The nlant generally sold under this name (the true $\mathrm{C}$. Palmeri is not in cultivation), is a charning thing, slender, resembling the last species, but in coior. a delicate lilac. shaded to salmon, ard with short yellow hairs on lower third. A good grower and very pretty 
A species related to C. splendens, hut with stems sn weak as to almost be sitid to creep. The flowers are large and very brilliant, a dazzling purple with a darker purple eye. and yellow hairs belew. Introduced by myself in $\mathrm{I} \mathrm{S}_{97 \ldots \ldots} \ldots$

\section{GROUP II-IENLSTLS}

Butterfly Tulips. To this lwelv group of Calochorti is properly applied the Spanish name Mariposa (butterfly), for their. brilliantly colored flowers with eye-like spots ' n each petal and sepal, and other delicate markings with dots, lines and hairs, are strungly suggestive of the wings of a brilliantly colored butterfly. Botanists have variously divided this great group of allied furms between Calochortus 'uteus and $C$. venustus. Botanically all can be considered as etther strains of one variable species or as a number of closely allied species.

\section{The Rosfus Strain.}

\section{CALOCHORTUS VENLSTUS Dougl. Var. ROSEUS.}

This is the type as described by Bentham, growing in the Coast Range of California. 6 to to inches high, stout. Petals brcader than long, with a short, broad claw. Flowers two inches across of exquisite shading. Creamy white or suffused with lilac. A rose colored blotch at apex of petal, fine eye midway, red shadings on lower third of petal. Back of petal rich carmine. Well figured in Garden in ' 85 . Var. SULPHUREUS

Exactly like type but color clear yellow, rose blotch at top of petal as in roseus. This fine novelty is offered by me for the first time. Supply doubtful.....................

\section{Var. SANGUINEUS}

In this showy form the flowers are deep red with very dark eye, and without rose blotch at apex.................. Var. PURPURASCENS.

Flowers like var. roseus: fully three inches across, purplish lilac outside and top of petals, cream! white half way, purple at center. A beautiful eye in middle of petal, but no rove blotch at apex. This strain is a strong vigorous grower, the best of all except C. Vesta. On each stalk are several larye offsets which soon form fine bulbs. It is natural to a rich, heavy, sticky clay, but thrives in an l.am. Colored plate in Garden, I 895 . 


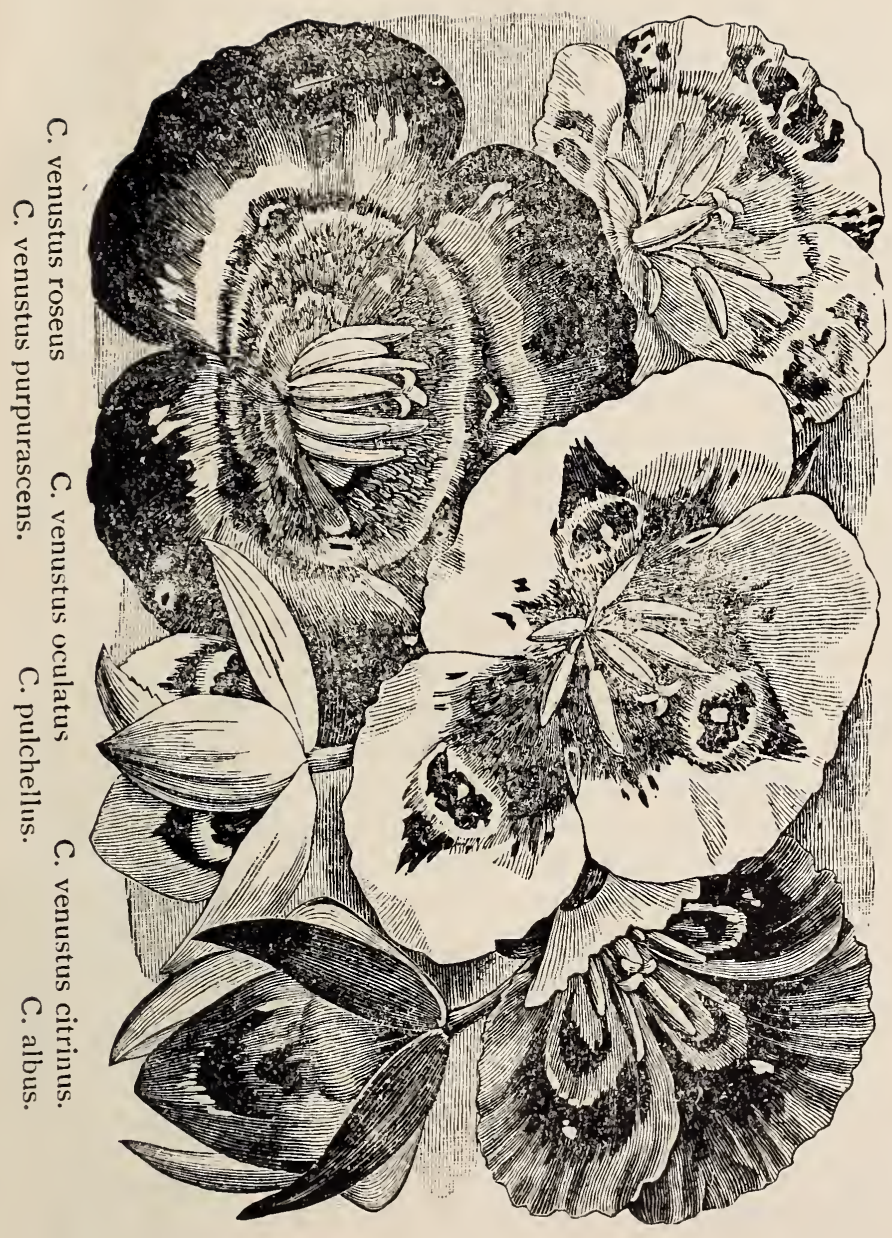




\section{Ei D)RAD.) STRाM.}

This lovely strain introduced and named by me in $\mathrm{IS}_{95}$ is botanically close to the var. roseus, yet to the eye clearly distinct. It is of much talier growth, being from ten inches to thee feet in height. Fetals are narrower than long, drawing to a narrow claw, and giving quite a diferent cutline from var. roseus, with its very broad petals and short, thick clew. In culor it is unsurpassed. In the same locality it varies from white, through li as. deep velvety purple. and reddish purple, to rich red, pink and s Imu i. All are marked with a showy eye. colored brown and with yellow, and bzalltifully dotted and lined. All have a showy red center, while to sime is added a larye gold blotch at apex of petal. There are also fine forms i. cream and light yellow.

The different color forms also grow separately and I am Each Duz. able to furnish in reliable separate colors.

El Dorado strain, mixed selected bulhs. Giving them in the wide range in which they naturally occur, the white most frequent, next purple, while the red, salmin and piniare rare

C. renustus var pictus. A fine color form of the El Dorado strain. Creamy white, brilliantly marked with or without gold blotch. Described in Gardener's Chronicle, July 6, IS95

EL Dorado deep purple: a deep rich purple of a velvety lustre, a depth of color unsurpassed in any flower.

El Durado, red to prn's. A spientid cilection of colored forms, scarceiy anv two alike. From pink to a deep claret and blood red. A dozen will give endless surprisen...

\section{EL DoRAdo Gold Blotched:}

These lovely flowers are blutched above with red or yold. Their Deauty can only be appreciated on sight. Ground color white, red or purple

\section{OCEIATES Straix. \\ I CALOCHORTLS VENTSTLS OCTIATI"}

These well known varieties differ only in colnr. ITith their variations they form a well marked strain. They have short, stiff stalks, one th three feet high, few to many flowers, with prtals bro:td at apex and tapering to a narrow claw. Well grown plants produce flowers three to four inches across. Colnrs from white and cream. through lilac to purple. in nculatus. Buff, to deep lemon yellow and brown, in citrinus. The eve is prominent. Center purplish in oculatus, brown in citrinus. A good grower and one of the very best species. 


\section{Var. CITRINUS.}

The splendid stran I offer is of a uniform deep lemon yellow with a black eye. No plant that I grow is more admired here or attracts more attention in foreign exibitions...

03 หก

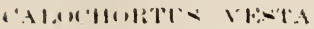

This very clearly marked strain, is unt related to any of the others. I consider it the finest of all Calochorti The habit is tall, strong and vigorous. The immense flowers three to five inches across, are borne on long stalks and are numerous. Petals hroad fan shaped with hairy gland across base, and a broad eve and band across middle. Color white. suftused with lilac to rose purple. Center red. Back of petal purple. It grows in any snil, from heary wet clay to light loam, and is not subject to) disease. It propagates rapidly, having severai strong offsets each year. which in two years make large hulbs Reports from Europe are that it succeeded where all others fail. This splendid species is what has heen long desired: a hardy. vigorous Mariposa tulip, which everyone can easily grow. "The five forms of venustus are among the most beauti" ful. Var 'Vesta' the strongest and perhaps finest of all." Geo. F. Wilson in Garden. Snlendidly figured in Garden, July. I895. Described in Gardener's Chronicle. July, 1895. Good, bulbs................. 5 Very large................................................ 10 1.00

\section{CALOCHORTUS LUTEUS Dongl.}

This is a dwarfed species, with rather small, full flower, a clear light yellow, brown lined at bast.......................... CALOCHORTUS CATALINAE s. Wat.

A lovely species between C. splendens and C. venustus. Habit of C. venustus. Flowers white to lilac, or deep lilac, very large and handsome, a large round black spot at base of each petal. Remarkable for blooming with the Star Tulip section, fully a month before other Mariposas. A splendid sort..........................................................

\section{Group III-CLAVATUS}

\section{CALOCHORTUS CLAVATUS $\mathbf{s}$. Watmon}

In this really splendid sort we have at once the largest flowered and stoutest stemmed of all Maripnsas. The bulb is verv large, the single bare leaf one or two feet long. the stem is heavy and stout zigzagged. The flowers are shaped like a broid based bowl, sometimes five or six inches across The color is a deep rich vellow, and the lower half is covered thickly with stiff yellow hairs, each tipped with a round translucent knob, and in the light like tiny icicles. I offer three lovely fo: $\mathrm{ms}$.

Var. EL DORADO (C. Plummerae aureus):-

The largest. Not so deep a yellow 
"Ventura" [the type]:-

Eich Noz.

A deep yellow. Very stout. Splendid.

20200 "Obispo"

Like the last but the upper half of the hack of each petal is olive brown which shows through the deep vellow of the inside, giving changeable shades A very lovely flower .....

CALOCHOKTUS CONCOLOR (C. luteus coneolor Baker).

The flower of this fine speries is a deen vellow. marked with red bands, and hairv on lower part incide. Stem not so stiff as C. clavatus nor is it zigzag. "こ. luteus v. concolor will be a great addition with its strong habit and clear yellow flowers." - Robt. Wallace in Garden. Colned Plate in Garden I895: Supply uncertain.

\section{GRITP III-IVEEDII}

\section{CALOCHORTUS TEEDII Wood.}

This is one of the finest. The bulb is heavilv coated with fibre, there is a single broad, radical leaf, and large flowers. Petals of a triangular outline, often square at the tip, clear orange yellow, finely dotted with brown, and lined with long silky hairs. There are also variations to light purple and brown. The type orange yellow. ....................

Var. ALBA

White or white flushed with pink. Surnly unceratin.

CALOCHORTUS PLUMMERAE Greene.(C. Weedil purpurnsens)

A queen among Calochorti. Of large size and full outline. In color a rich lavender purple, lined with long silky. yellow hairs.

\section{CALOCHORTUS OBISPOENSIS LEMn.}

A unique form of $\mathrm{C}$. Weedii in which the petals are less than one-half the length of sepals, densely covered with long brown hairs. Habit tall, slender and branching, very floriferous. A genuine novelty

\section{GRרU IV-IIESERT SPECIES.}

\section{CALOCHORTUS KENNEDYI Porter.}

This "is the mort brilliant and striking of all the Calocherti known to us," says a writer in London Garden, who adds- "the dizz! ine scarlet of the flowers suggests the iodide of mercury. and as the nlaut prives to be what is called a good doer, it is certain to become p ppul ir. It has iroved perfectly hardy in England, the bulbs having been in the open border 
during the last three winters, and flowers have been produced in abundance during the summer. It grrows about is incher high. The flowers are produced in umbels of 4 or 5 , the outer segments being pale green on the outside, with white scarious margins. The inside is briiliant scarletred, the inner segments also brilliant scar et except for a !urple spot just above the base bearded with a tew tufted hairs; the anthers are dark purple."

$20 \quad 200$

\section{GroIP V-NUTTALLII.}

There are no more exquisitely beautiful flowers than these

Each Doz.

"Segu Lilies" (The Mormun name) of the Great Basin. Must of them are plants of the sage brush desert-. The leaves are an ashy green, the foliage scaut, but the great flowers are wonderful in tintings. I offer C. Nuttallii white, often sold as C. Gunnisoni; large, pure white thwers handed green on the back, and marked dark brow'n inside.

c. Nutrallii blue. Very Large, flowers white to blue marked indigo inside. Supply uncertain....................

C. Nuttalliı yellow

I5 I 50

C. Nuttallii in pink shades. Supply uncertain

C. Nuttallii in lilac and purple. Supply uncertain............

\section{CALOCHORTUS LEICHTLINII Hook, J.}

C. Leichtlinii is a slender Alpine specirs, of a smoky white colur, banded green and marked dark brown

C. invellustus (C. Palmeri of 1894). A stiff umbellate species, a smoky white Supply uncertain .................... green, a band of green hairs across petal, and a purple band below

\section{GKoLP VI-CALOCHORTUS MA ROCARPUS Dourl.}

This very tine species forms a group by itself. It has a very lalge bulb; a stout almost leafless stem, and a very large fower of an exquisite pale lavender banced down the back with green. Petals long, narrow and pointed

\section{Group VII-NITIDUS}

These are hardy species growing in the meadows from Oregon to Montana, where they endure much cold. They form a connecting link between the Giant Star Tulips and the true Mariposas. Their leaves are like those of the Star Tulips, long, broad and glossy. Like the Star Tulips too the seed pod is handsome, three cornered and winged. The stems are stiffly erect. The flowers cup-shaped, not so billiant as the true Mariposas, hut 
very delicate. The plants are hardy, healthy, and vigcrous, and are to be highly recommended for cold climates.

CALOCHORTL'S NITIDLS Dougl.

This species has a larye showy Hower, pale lilate with a large indigo colored blotch in the centre of each petal. It is lined with long cohweby hairs Ready Sept Ist.

('. pavonaceus. Not quite as large. Lilac with a peacock like spot on each petal.....................................

\section{CALOCHORTLS LONGEBARBATUS}

A good species in same line. Purple...................... c\& So

\section{Section II.-STAR 'TUI.IPS \\ Group I-GLOBE TULIPS}

These have a shiny leaf often a foot long. The stalks are slender, branching in graceful curves. Few to many flowers are borne, of the most exquisite silky texture which hang in pendent globes. These are the perfection of grace in outline and while not brilliant are unsurpassed in delicate tints. Plants of the woodland

\section{CALOCHORTUS ALBUS Dougl.}

Fairy Bell, White Globe Tulip. A strong grower, often a foot high with ten to twenty globular fowwers of an exquisite pearly white. The flowers an inch in diameter, edged with silky hairs, and hanging like bells

C. amœnus. Much like preceding but a glowing rose pink

Like preceding in leaf and stem, but the flowers flattened like a childs' pin wheel, of a golden yellow beautifully margined with stiff hair:. A perfect gem, no collection is complete without it.................................

\section{GROUP II-ST $\Lambda$ R TCLIPS.}

Like the Globe Tulip but smaller as a rule, and the flowers dainty open cups. All of the species resemble each other, and were first included under $C$. elegans.

\section{CALOCHORTL's ELEGANS Pursh.}

A dainty sort with cream colored flowers lined with yellow hairs. Suply uncertain. Ready Sept. 15th..............

\section{CALOCHORTUS MATEANUS Lelchtl}

Cats Ears. Flowers white, filled with silky blue hairs, very dainty 
C. maweanus $\%$ roseus, same tinged rose.....

Each Doz.

C. maweanus $v$. major. Twice as largu in every respect,

otherwise the same.

06

06

60

CALOCHORTUS CAERULEUS S. Wat.

Like preceding but blue lined with long silky hairs

os

So

CALOCHORTUS BENTHAMI Baker.

Like preceding, but a rich yellow with black spots..........

c. LOBBII.

An alpine species dwarfed, but large straw colored flowers with dark eye, very odd and pretty. Supply

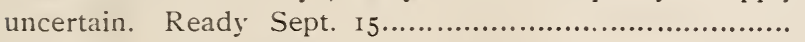

CALOCHORTLS UMBELLATLS Wood.

Like C. maweannus, but flowers not hairy, and white. Supply uncertain

c. MIxmes

A tiny species with naked white flowers

\section{GROUP III-GIANI'STAR TLLIPS}

In this splendid group which until offered by me this season was hardly known, we have the very dainty silky flowers, and handsome glossy leaves of the Star Tulip with a stout stem a foot or two high, and large flowers. Unlike the others they naturally grow in open places and have a vigor and health which are a high recommendation. They are sure to become great favorites.

C. new sp. No. I. A perfect beauty, with a large white cup, filled with hairs

CALOCHORTUS TOLMIEI Hook-Arn.

Same but blue Supply uncertain

C. Howellii Yellow. Very fine.

CALOCHORTUS APICULATLS Bak.

Straw colored, a gem. Supply not sure

20

\section{Section III.-MFADOW TLLIPS}

These Calochorti are natives of wet meadows. Of all the Calochorti which I have grown, I have found C. lilacinus and C. Vesta growing well in all soils as long as well drained, and, as garden plants, thriving everywhere. In habit they are low flexuous and leafy. The cups are open and erect and numerous, an inch or so in diametar. I have closely studied the matter and have come to the conclusion that $C$. lilacinus and $C$. uniflorus are one and the same species. 
CALOCHORTLS LILACINU'S K=llcgg

F uwers from pale lilac, with or without a dark blutch at Doz. base of peta! ................................................. 35

CALOCHORTLS NUDUS S. Watson.

A delicate sort, with pale nak d fluwers .................... I oo

Mixed Calochorti:- all sits nixed, doz :ar.

Mixed Mariposas

$\therefore 1^{\prime} c$.

Mixed Star Tulips

$2 . x$

\section{Cam?s sin.}

A. class of very harly hubs of sturily growth and hardy in any climate and almost any soil. The cur de-cribes the flower. The plant has many long and glossy leaves from its base much like a hyacinth. The stem is stout, from one to three feet high, according to variety. The many flowers are borne in racemes. Flow rs for every ones yard and window.

CAMASSIA ESCULENTA Lindi. Each Doz.

$A$ fo $i t$ high, deep blue.................................... $03 \quad 30$

CAMAESA CTSICKII.

I take pleasure in bringing this grand new species within the reach of the general public. It is destined to become a general favosite. I have grown it for three years very successfully. The bulbs are very large. weighing from two to eight ounces. The leaves large-a foot long The flowers produced in great racemes two to three feet in height, and with hundreds of pale sky blue flowers.

I5 I 50

\section{CAMASSIA LEICHTLINII S. Watson.}

So far as I have seen this is the finest Camassia in flower, tall, and a splendid purple. Ve.y showy.............. of 60

C. alba. A pure white form ................................ In I $\infty$ CAMASSIA FRASERI Torr.

Light blue............................................... o o 60

C. montanum A beautiful species like C. esculenta, a pale sky blue, flowering after all others....................... o. o6 60 


\section{DOG TCOTH VIOLETS.}

\section{Genus ERITHRONIEM Linnan.}

These charming lily-like plants have two broad handsome leaves, growing from the ground, which are usually richly colored and mottled, and in themselves very ornamental. The slender leafless stem bears lovely flowers, which are like small lilies, of exquisite coloring, and droop gracefully. They are perfectly hardy anywhere, and grow best in a cool, moist climate and a sheltered location. Their culture is easy, a well-drained loose soil, rich in mould, perfectly meeting their requirements, and they flower early when all flowers are more appreciated. With so much of beauty, and so many excellent qualities, they cannot help becoming immensely popular. The European and Eastern American sorts are not to be compared with our large fowered sorts. All are beautiful, and cheap or dear every one will prove a delight.

Our Pacific Coast Erythroniums are the finest known. All are large of flower except E. purpurascens, and differ but little in that respect. They differ much in time of flowering: E. Hartwegii is very early: it is follewer by E. revolutum præcox: then Hendersonii, grandiflorum (type), grandiflorum album. and purpurascens follow; the next in flower is revolutum Bolanderii, followed quickly by revolutum Johnsonii; next comes giganteum and revolutum (type); revolutum Watsonii lingers after all the foregoing have gone, and montanum comes weeks later.

The delicate shadings, from white to bright yellow, while very difficult to describe, are easily caught by the ere, and give a charming variety. Accompanied as they are by difference in their flowering season, habit, and mottling of leaves, a charming chain of variation is given, no links of which we would willingly lose.

Section I.-Strle Three Cleft.

\section{ERYTHRONIUM GRANDIFLORLM}

Fach Doz.

Leaves unmottled, I-F-flowered, stem slender, petals recurved, flowers very bright vellow, anthers yellow; I distributed this last year as Nuttallianum, and under that name it has been exhibited in London, and has been very greatly admired......

Var. ALBCM.

Like the type, except the flowers are white, yellowish at center, and with a slight greenish caste. I have distributed this for two years past as the type; a very fine species.........

\section{ERTTHRONIUM NUTTALLIANUM}

In no way differs from grandiflorum, except in having red anthers; I have no bulbs of this. 
Leaves mottled in white and light brown, one to four, nearly alwas one or two flowers, stem stout, petals narrow and curved, style large and stout, filaments from subulate (awlshaped) to deltoid (triangular); flowers opening from white flushed with pink, to pinkish-purple, becoming purple. Mr. Baker, the well-known authority, pronounces this the true revolutum; listed in 1896 as "revolutum, large purple"........

Var. BOLANDERII (E. Smithii).

Differing from the type in having white flowers, tardily becoming purple, and in being smaller.

Var. JOHNSONII (E, Johnsonii).

Very similar to the type, but leaves mottled in dark brown and looking as if coated in varnish, and flowers dark rose, with orange center; a fine colored plate of this was published in the London "Garden" February 20, I897..............

Var. PRA:COX.

In this charming variety, which I have named Præcox, the leaves are mottled in mahozany, the most beautifully in any Erythronium; the flowers, usurlir two to four, are creamy white with orange center; I distributed a few of these in 1896 as E. citrinum.

Var. IVATSONI.

Differs in having a full creamy white fower, orange at center, and usually banded with brown above the base; in foggy weather the flower is bell-shaped. One of the finest of Erythroniums; leaves mottled in brown; this, according to Watson, is the typical form of the species, but according to Baker, it must be given a varietaI rank

Var. ALBIFLORUM.

This only differs from var. Watsoni in being pure white, with a delicate greenish caste. It was figured perfectly in plate 9I9 Horto Van Houtteano, which is Krelages' plate roor A. Also called E. giganteum albiflorum, and E. grandiflorum albiflorum

\section{ERYTHRONIUM GIGANTEUM Linđl.}

Leaves richly mottled in dark brown, scape one-to sixteenflowered, slender, filaments slender, flower closely recurved, straw colored, orange at the center; the most floriferous and one of the finest species, long known as grandiflorum......... 
The easiest of all to grow: short, thick bulbs, of great vitality, and flowers like giganteum, but each borne on a tseparate stalk; one of the best and most satisfactory sorts.....

E. MONTANUM.

Like E giganteum in flower, but pure white with orange center. Leaves not mottled.

Section II. - Strle not Divided.

E. CITRIXUM,

Leaves mottled, stem I-3 flo wered, petals broad, strongly recurved, light yellow, orauge at center, the tips becoming pink. I have never had this species, and do not know of its ever being distributed. The mottled leaves and uudivided style, with yellow flowers, mark it clearly. I have none.

E. HENDERSONII.

Leaves mottled in dark brown, petals strongly recurved, pa'e purple with a very dark purple, almost black center.

E. PLRPCRASCENS.

Leaves not mottled, shaded in dark metallic tints. The small spreading flowers crowded in a raceme. Color; light vellow (almost white), center orange, becoming purplish. The smallest of our Erythroniumas. Properly an alpine.

E. How ELLIT.

Leaves mottled, scape I-3 flowered, flower pale yellow with orange base, becoming pinkish. Of our Pacific coast Erythroniums this alone is destitute of the ear shaped appendages at inner base of petal...............................

\section{Fritillaria.}

These are graceful plants usually called lilies where they grow and the nearest relatives of the true lilies All are gractul, many interesting from their peculiar coloring. and some are very beautiful. Few lilies are handsomer than $F$. recurva and $F$. coccinea.

\section{GROLP I}

These are rather low. The leaves scattered thickly on the lower part of the stout stem: and the broadly bell shaped flowers nodding above. The bulb is formed of large broad scales. These are very hardy, growing well on heavy soil, and increasing fast. excellent garden plants. 
FRITILLARIA BIFLORA Lindl.

Each Doz.

Flowers with a greenish ground, with brown rays radiating from the base to apex of the petals.................. FRITILLARIA LILIACEA Lindi.

Very similar, greenish white, not lined...................... FRITILLARIA PLURIFLORA Torr.

A really splendid thing, first brought out by me two years ago, and a growing favorite. Large and strong. growing, with beautiful reddish purple fluwers, blouming very early (in January here) .................................

\section{Group II}

In this group the stem is tall and slender, with the leaves all in circles, and the flowers strung airily in a drooping raceme. The bulb is a pure white or pink disk covered with rice like grains.

\section{FRITILIARIA LANCEOLATA Pursh}

A strong, tall sort with large greenish bells mottled with yellow and purple...... .......................................

Var. gracilis: Similar, but the smaller flowers a dark purple, almost black...

FRITILILARIA PARVIFLORA Torr.

This is like F. lanceolata in stem and leaf but the flowers are small, in solid colors, yellow, or brickish red. Rather pretty..............................................

FRITILLARIA ATROPURPUREA Nutt

Similar, but greenish purple and stiff bells queerly mottled, on very short stems... ..............................

FRITILLARIA RECURVA Benth.

The finest Fritillaria in the world. Tall. Flowers many, between tubular and bell shaped, a brilliant scarletorange in color. A perfect beally

Immense bulbs $1 \frac{1}{2}-2^{1 / 4}$ in diameter.

Large " I $1 / 4-11 / 2$ " "

Fine

" $1-1 \frac{1}{3}$ "

Fair

، $3 / 4-1$

06 60

$05 \quad 50$

FRITILLABIA COCCINEA

Even handsomer than the last, which it resmbles. The flowers narrow and a deep glowing red, not so robust as $F$. recurva, and bulbs much smaller. 
FRITILLARIA PUDICA spreng.

Each Doz.

A most charming one or two flowered species, rich orange yellow. A great favorite where known. Colored plate in L.ondon "Garden.'

\section{LILIES.}

\section{GROL' I-HUMBOI.DTII.}

LILILA HUMBOLUTI.

A grand lily, with a large bulb, a heavy stem four to seven feet high, with very numerous leaves all in circles, and large flowers of a clear orange red spotted with maroon.

Bulbs 7-8 in circumfrence

Ready September Ist.

" $8-9$ "

15 I 50

20200

25250

VAR. MAGNIFICUM.

A very fine variety which every one should have, As large as preceding, but glossier and darker foliage, and each spot surrounded with a red curcle giviıg a gorgeous effect. It is a reliable bloomer, flowering the first season. even from small bulbs, and is a grand acquisition to any garden. Ready Sept

LILIUM BLOONERIANUM Kellogg.

A dwarfed species, with flowers colored like the last, only one to three feet high with small bulbs. Ready Sept. Ist...

LILIUM COLUMBIANUM Hort.

A beautiful slender lily one to three feet high, a minature 1. Humboldtii, orange yellow: very easily grown

LILIUM BOLANDERI S. Watson.

This beautiful lily has been the rarest of all. In bulh and habit it somewhat resembles L. Columbianum, but the flower is bell shaped and deep red Quite showy..... .

\section{GKOUP II-LEOPARD LILIES}

L. Pardalinum

A fine lily prefering a rich damp soil but doing well in any garden. I.arge revulute flowers orange red at center, scarlet tipped. thickly spctted with maroun. It is so easily grown and is so handsome that it shonld be found in every

garden. Ready September ist...................................
The form I have is close to the so called I.. Californicum. 
So far as I have seen the best variety of L. Pardalinum, very stout and tall with rich dark foli.tge, and a fine flower. the upper half a glowing crimson, very showy. From British Columbia. Ready September I 5 th ...........................

IILIUM ROEZLI Regel.

A very handsume lily first intriduced into Eur pean gardens by Roezl about 1870 and figured in Roezl Gartenflord t. I66. It afterwards was lost and even the name appropriated for a mere color form of $\mathrm{L}$. pardalinum. Well described by Baker. In general habit it is like L. pardalinum, but the bulbs do not form clumps. The petals are reflexed to their base, the color throughiout a brilliant orange red exactly the color of L. Humboldtii, not tipped with red as in all forms of L. pardalinum. Spotted dark purple, One of the prettiest of Pacific Coast lilies. Ready September Ist.

L. PARRYI

One of the finest lilies in the world Bulb and leaves as in the last, but long trumpet shape flowers, of a fine lemon yellow, and very fragrant

\section{GROLP III-PARVUM。}

Slender lilies with a rhizomatons rout, native to moist stream sides or peaty soil. When well grown they attain a height of three to five feet with many flowers.

\section{LILIUM PARVUM Kellogg.}

A charming little lily from the alpine regions of the Serra Nevada in the Lake. Tahoe region. The flowers are funnel form, and small, a veri brilliant orange red dotted marwon. pale ltaves light green. Ready Sept. 1st. ......................

L. Parviflorum

Exactly like $\mathrm{l}$. parvum in bulb and general habit but stouter. The flowers revolute, resembling small L. pardalinum, and flowering a month earlier $(L)$ pardalinum

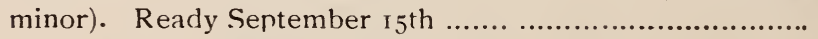

\section{LILIUM MARITIMUM Kellogg.}

A rare and beautitul lily, with very dark green foliage. The narrowly funnel form flowers deep red. spotted purple in the throat. Ready September $\mathrm{I}_{5} \mathrm{th}$........................ 
LILIUM WANHINGTONIANUM.

A luvely lily growing from four to seven feet high with many pure white, very fragrant, trumpet shaped flowers. There are, several forms. My supply is of cu'tivated bulbs grown in Oregon, and of a hardier better growing character than those of the mountains of California

VAR. PURPUREUM.

$\begin{array}{llll}7-S \text { in diameter. } & 20 & \text { I } 75 \\ 8-9 \text { " } & \text { " } & 25 & 200 \\ 9-\mathrm{II} & \text { " } & 30 & 250 \\ \mathrm{II}-\mathrm{I} 5 & \text { " } & 50 & \end{array}$

This is a pink variety of the Oregon form of L. Washingtonianum and exceedingly beautiful A colored platein Van

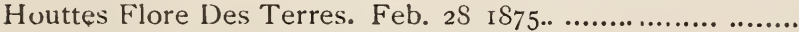

LILIUM RUBESCENS S. Watson.

California's handsomest lily, like preceding in stem and leaf. The flowers in a shorter tube with fuller petals, opening pure white turning first pink and then deep wine color. with fresh flowe's of these colors at one time. ()ne of the most delightful of perfumes It is not a hard plant to grow hut the hulbs are very liable to decay. I can ship splendid bulbs in pertect shape in Nurember...

\section{Trillium.}

\section{T. SESSILE Var. CALIFORNICUM}

A splendid plant exactly like figure. Petals three inches long, pure white It has a tendency to grow severa! plants in a clump

Var. RUBRA: exactly as in former, except the color is a deep red purple.

T. OVATUM.

A fine sort, resembling the eastern T. grandiflorum. white, turning to wine purple

\section{Some Odd and Novel Bulbs and Plants.}

\section{HEIPEROCALLIS UNDULATA}

The Lily of the Desert: one of the most lovely of flowers, inhabiting the sandv wastes of the Mohave and Colorado deserts, where the large flowers of waxy whit-ness, or tinged with green, "waste their sweetness on the desert air" 
MreiLLA MapiTIMA S. Watson.

Fiach Doz.

An early flowering bulbous plant with greenish w'ite

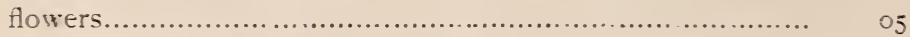

CHLOROGALUM POMERIDIANLM KT.

A large plant with leaves like a Camassia, a tall many branched stem bearing a great number of star like little white flowers, and a large bulb used for soap by Indians....... CHLOROGALUM A.NGLSTIFOLILM $\mathrm{k}$.

Six inches, to a foot high

CHLOROGALLM PARTIFLORUM S. $\pi$

One to two teet.

ALIITM TNIFOLILA Kellogg.

A really handsome leek with large head of pink flower: ZFGADENTS FREMONTII Torr.

A bulbous plant with leaves like a Camassia and a tall stem with a number of go id sized greenish yellow flowers, quite fragrant and fluwering very early. This plant is pretly enough tu deserve a place in the hardy garden. Very hardy and easily grown

\section{A Few Beautiful Plants.}

Clintonia Andrew siana. One of the handsomest of woodland plants, having many large and handsnme leaves spreading from the base. The stem is slender and hears a number of handsome pink tubular flowers. The fruit is no less beautiful, purple. It grows in deep cool woods in a clayey soil rich in mold. I wruld not recommend this to all but for those who can care for it it is a gem. Ready Oct. Ist

Cypripedium Montanum. This is nur large western L'ıdies' Slipper. It forms a clump producing many stout leafy stems one or two flowered. A lovely flower. It grows in shade in a loose perfectly drained soil rich in mold. Ready Oct. Ist.

C. Californicum. A handsome bog variety of the Lady Slipper. Ready Oct. Ist......................................

Dodecatheon Hendersonii. Shooting Star. American Cowslip A beautiful early flower, deep rose. Easy to grow:

D. Clevelandii Lovely pale pink or white....................

D. cernuum. Yellow-flowered

Leucocrinum montanum. A very lovely early flowering lily-like plant with pure white fragrant flowers. To be grown in sandy soil. 


\section{Culture of Calochorti and Brodiaeas.}

The culture of these bulbs in such a clmate as that of California, where I5 degrees above zero marks the lowest degree of cold is the easiest matter possible. They only need loose loamy soil and perfect drainage. I have had the best success as follows. Make large boxes of 1 wo inch plank, ten inches deep. In the botton place two or three inches of good drainage material, such as gravel or broken brick. Fill up with a light loose soil, sandy loam is goud, a mixture of leaf or chip mold is better, but I have had the best results with about $1 / 2$ lom to $1 / 2$ spent tan bark, haif rutted. Note the soil recommended below. All of the bulbs will do hetter with a light shade. Erythroniums must have a shady place. An excellent shade can be made with narrow laths or slats nailed on a light framework. Caluchorti and Brodiaeas should be planted one or two inches deep, and will thrive one and a half inches apart. When the bulbs are in and covered, it will be found that half an inch of sharp sand will save much wreding. In such a bed the bulbs are safe from gophers and moles. It is better to plant where they will be shaded a part of tbe day. If it is desired to grow in pots or 1 ans, use sinilar soil and be carefui to give groud drainge. The pots can be plunged in sand till blooming time or kept in a cool situation or l.andled as hyacinths are.

In Garden and Forest of July 7 th 1897 Mr. J. N. Gerard of Elizabeth N.J., a sticcessful amateur, writes an interesting letter 's the culture of Calochortus from which I extract the following.

"It is probable that many who have ventured to grow them have been disappointed in results, for the cultural directions of the catalogues are usualy more or lees incorrect. They often recommend cultivation in frames or uther conditions which deter most growers from attempting their cultivation. My experience with all the species is that they are not tender nor at ali difficult to flower in this latitude in the ordinary garden border. (alochortuses grow naturally in regions rainless in summer and where dormant plants waken into growth in the fall under the influence of moisture, but not necessarily of a light tempreature. They re harly here without prote: tion but must be classed with those bulbs whose foliage will not always endure the rigor of our winters. The succrssful growih of such bulb; requires that after being thoroughly ripened in the early summer they shail be kept perfectly dormant so late in the yrar that no foliage can appear above the ground until early in the ensuing spring. The simplest and safest procedure is to lift the bulbs after ripening foliage indi(ates dormancy, and store them in dry earth in a warm dry place, and plant out where the ground has lost its warmth which in this locality is in November. Under such treatment thev grnw and flower well here even in soil ton hard to work in (lry weather and with no other attention than that already suggested Of course one does not plant bulbs in manured soil or soil rich in humus which will hold water and ferment to their injury." 


\section{Culture in England:}

A successful grower in London "Garden" write: "A large raiced bed, formed in November, and sloping to the south, was composed of leaf mold and road grit in equal parts, with a similar portion of sharp sand. The bulbs were planted three inches deep, and the whole bed was covered with weeds to throw off the heav' rains and keep the soil onen. Nany young growths appeared early in January, and by the end of February nearly al] were showing above ground. The weeds were then removed. In my opinion a good many failures to yruw calochorti may be attributed to late planting. The main points in the culture of calochorti are early planting, a light porous soil, sunny position, protection from heavy winter rains, (but not coddling), plenty of water whilst in full growth, and throughi ripening of the bulbs in August, either by taking them up or placing lights over them."

I would add that experience in Fngland is tending to show that late planting is often best.

I find that Calochorti which are subject to mildew do better if planted in January or February. This is especially true of the desert species such as C. Kennedyii, C. Nuttallii and C. macrucarpus. Fur these I would always recommend late planting.

\section{Culture of Erythroniums.}

These are hardy anywhere. They like a shady place, and requires good drainage. The soil recommended for (alochortus meets their needs well, but will grow in any good loam. Be sure that your bulbs are kept fresh. Some sorts dry out quickly and it will not do to leave tbem exposed to the air or in a dry place, Your success will depend largely on starting with plump solid bulbs, and early planting is desiratele.

\section{Culture of Californian Lilies}

Lilies of the Washingtonianum and $H \cdot 1 m b o l d t i i$ ginups should have $?$ good deep soil with good drainage, thev do better in partial shade as ain ong shrubi or ferns. Plant at least six inches deep.

The lilies of the pardalinum group are verv easily grown, in any g ind garden soil. A cooler place with a little shade, like a shrubbery bed, a fern bed or a stream sıde suits them still better and they make a gre at growth. The parvums are a little more delicate, and a little leaf mold or peaty soil will insure the finest growth.

The rhod'dendron bed is the ideal situation for all of our lilies. 


\section{General Notes.}

Plant early: October is no' to early.

Don't water continually. Suak up occasionally and leave alone as long as soil is barely moist.

Don't use coarse, rank manure, either barnyard or other.

1)on't force roo much. the longer the growing season the better.

Don't water after blommine-iry off, and if they cannot be kept dry, take up and lay away in a dry blace.

Dun't think because Cyliornia is a warm country that the winter climate is hot. The ground is , ften frozen stiff for a week at a time where these bulbs are native, and heat is to be avoided until the time of blooming. It will not hurt them if the leares are occasionally frozen stiff.

\section{Special Offers and Collections.}

Three each of 30 Brudixe is and B Bonmerias...................... \$2.50

Six " " " " . " " $\quad$ ".................... 4.00

Six each of the followine fine Brolice:-Rridgessii, laxa, lactea, ixioides, grancitima. clellaris, californira, capitata, coccinea' Volubilis, Duuglasii and Buomeria aurea. The cream of the collection. 72 fine bulbs for.................... 1.50

Three each of Forty surts if Caluchesti 800

Six ", " " " " "

Three ", ", Twenty fi e sorts of Caluchorti............... 2.50

-ix " " " " " " " " "

Six each of the followine twelve splendid sorts; viz., El Dorado Mixed, Ocula'us, citriıs, Jestr, luteus, Plummere. Gunnisonii, Albus, pulchellus, maweanus Benthamii and lilacinus. 72 fine bul is ................................... 1.50

Three each Twelve splendid sorts of Erythronium. $\quad 2.25$

Six " " " " " ..... 4.00

Ioo bulbs in fine mivture .............................. I.50

One earh Fifteen surts of liiies ............................ 3.00 



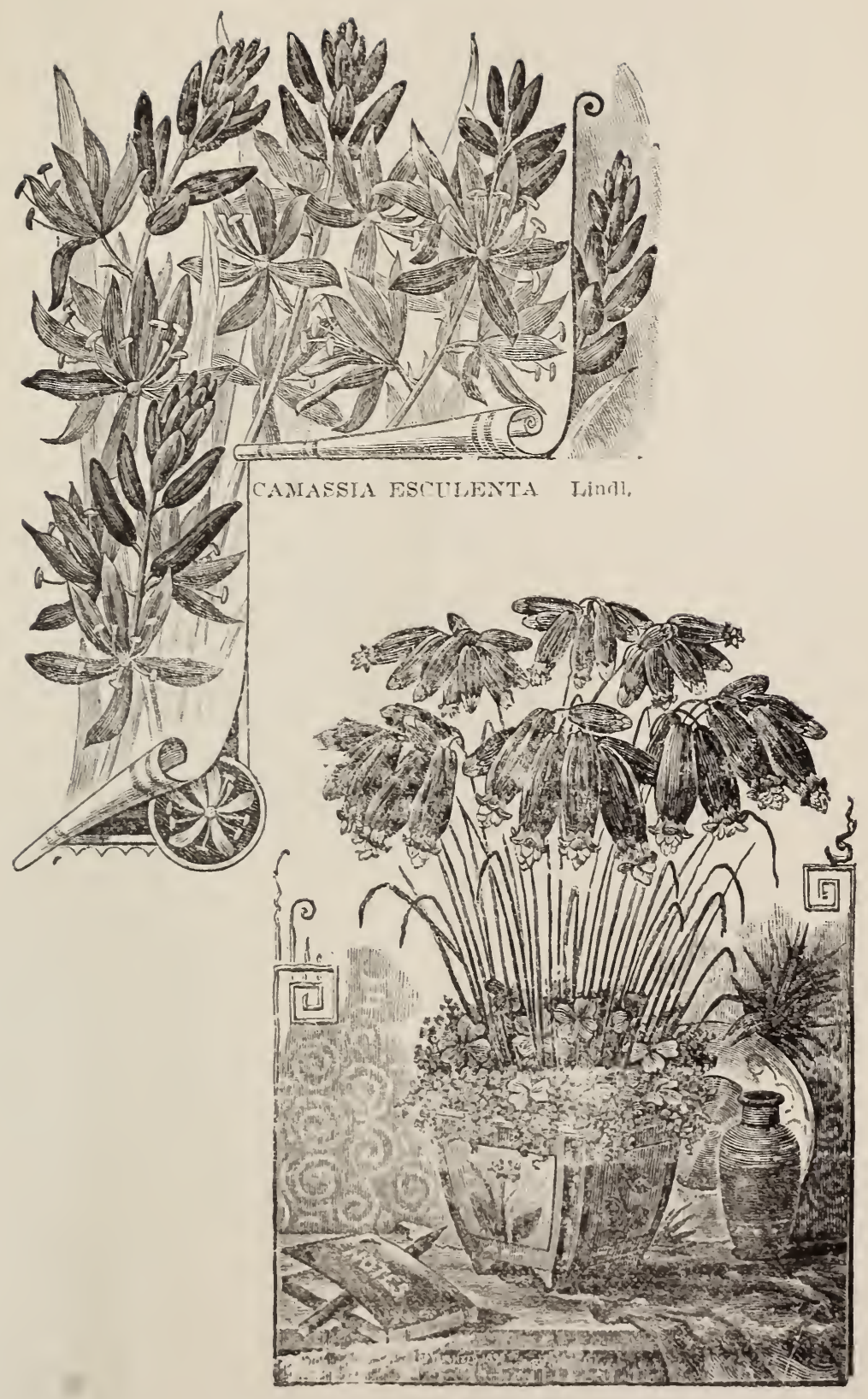

BI.ODIAEA (OCCINEA A Gray. 

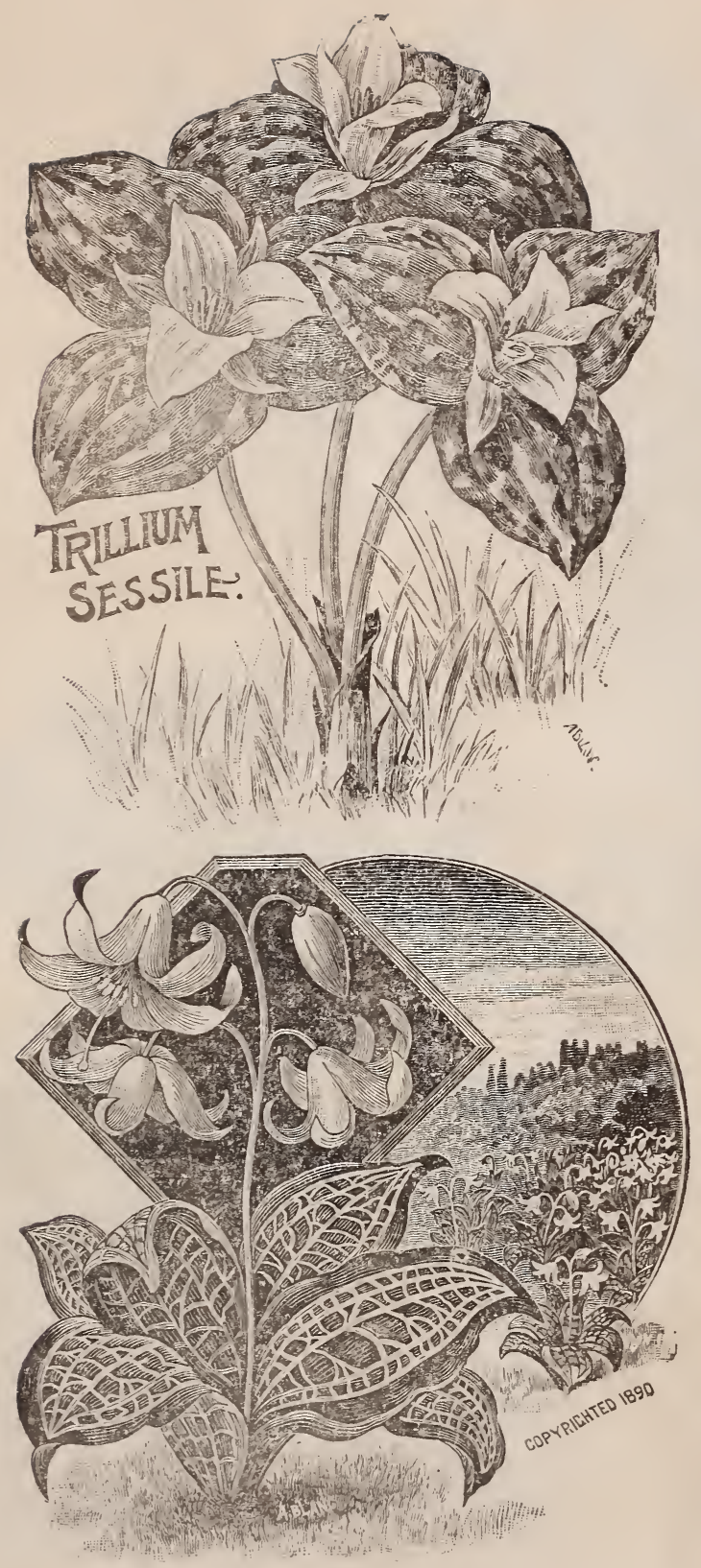

ERYTHRONIUM GRANDIFLORLM 